\title{
Belonging without believing: religion and attitudes towards gay marriage and abortion rights in Northern Ireland
}

Professor Bernadette C. Hayes*

Director of the Institute for Conflict, Transition, and Peace Research

University of Aberdeen

Dr Andrew McKinnon*

Senior Lecture in Sociology

University of Aberdeen

\section{Article history:}

Received: 21 September 2017

Accepted: 15 March 2018

\begin{abstract}
Same-sex marriage has become a divisive issue in established western democracies. As in earlier research on abortion, there is now a growing body of studies which suggests that religious factors, such as identity, belief and practice, are the most frequent predictors of opposition towards gay marriage. Yet, what we know about the combined influence of these religious factors remains unexamined. Mindful of this omission, this study examines the relationship between regular church attendance and a belief in God on attitudes towards same-sex marriage and abortion rights. Using recent survey data from Northern Ireland, the results suggest that not only are those who belong but do not believe distinctive in terms of their demographic makeup, but they are also significantly more likely to adopt a liberal stance in relation to both these issues - gay marriage and abortion rights - than the most religiously devout, or those who both belong and believe.
\end{abstract}

\section{Keywords}

Abortion; Believing; Belonging; gay rights; Northern Ireland; religion

*School of Social Science, University of Aberdeen, King's College, Aberdeen, AB24 3QY b.hayes@abdn.ac.uk and andrew.mckinnon@abdn.ac.uk 


\section{Introduction}

Public opinion provides an important barometer of likely future voting patterns and legislative recognition of gay marriage and abortion rights. As a number of scholars have noted, landmark legislative decisions, particularly at the national level, have often been precipitated by shifting opinions among the general public. This seems to be particularly the case when the question of gay rights is considered. In fact, some scholars go so far as to suggest that the political endorsement and legislative activity in relation to gay marriage in the United States and Europe reflects a 'sea change' in public opinion in support for gay marriage, particularly over the last two decades Brewer (2014). This is not to deny, however, that there are ongoing and heated debates, and some important differences, both within and between nations, in relation to this issue. There is also a notable East/West divide in Europe, with significantly lower levels of support for same-sex marriage as well as gay rights, generally among former communist countries, such as Poland (Fitzgerald et al., 2014).

Accompanying these changes in public opinion and legislative rights for gay couples, there is also a growing body of research examining the social correlates of attitudes towards same-sex marriage, albeit more so in the United States than in Europe and elsewhere. As in studies on attitudes towards abortion (Jelen and Wilcox, 2003, 2005; Froese and Bader, 2010; Barkan, 2014; Clements, 2015; Lizotte, 2015), such research finds that religious factors such as affiliation, regular church attendance and beliefs in and about God are among the most frequent predictors of opposition to gay marriage (Olson et al., 2006; Whitehead, 2010; Clements and Field, 2014; Hayes and Dowds, 2015). Religious communities have also been divided internally in their response to changing public views. In fact, some analysts go so far as to suggest that public disputes and differences in opinion over homosexual rights have now replaced abortion as the most significant and divisive moral issue facing many religious communities today (Wilcox, 2007; Badgett, 2009; McKinnon et al., 2011; Hayes and Dowds, 2015; Brittain and McKinnon, 2018).

Although an increasing number of studies have included religious measures in their analysis of support for either gay marriage or abortion rights, to date, little effort has been made to understand exactly how the effect of these religious factors, such as 
religious traditions, practices and beliefs, shape public opinion. Moreover, there has been almost no attempt to investigate how the two key dimensions of religious life practices and beliefs - intertwine in determining attitudes towards both these issues, even though sociologists have found interactions between belief and practice in their effects on a range of other outcome variables (McKinnon 2003; Paxton, Reith and Glanville 2014; Schieman et al., 2017). To date, studies that have been conducted have tended to adopt a singular approach, namely seeking to evaluate and compare the independent, or net, effect of each of these religious measures on attitudes towards abortion or gay rights. It is with this omission in mind that this study focuses directly on the link between religious beliefs and practices in assessing the impact of religion on attitudes towards gay marriage and abortion, currently two of most salient public moral issues in Northern Ireland (Thomson, 2016). More specifically, using data from the 2015 Northern Ireland General Election Study and applying the typology believing and belonging - it seeks to assess the degree to which the differing intersections of belief and practice are a key distinguishing factor in predicting attitudes towards both gay marriage and reproductive rights within this society.

The use of Northern Ireland as a case study may be considered particularly appropriate for the following three reasons. First, unlike many other western postindustrial nations, Northern Ireland remains a deeply religious society. Despite the subjective and voluntary nature of religious identification within this society, Northern Ireland continues to maintain a very high rate of religious belonging. Current survey data suggest that just over 90 per cent of the adult population selfidentify with a religious affiliation, the vast majority of which belong to either the Protestant (46 per cent) or Catholic (35 per cent) tradition. At eight per cent, there is also a small minority of religious independents - those who currently claim to have no religious affiliation - whose religious origins are primarily drawn from the Protestant tradition (Hayes and McAllister, 2013). It is important to note, moreover, that this religious affiliation is more than merely nominal: Northern Ireland has traditionally manifested one of the highest levels of religious observance found in Europe (Fahey et al., 2006). Second, unlike Great Britain, where abortion (albeit with some restrictions) and gay marriage are legally available, both gay marriage and abortion remain legally prohibited in Northern Ireland. ${ }^{1}$ Third, and contrary to many other 
western industrialised societies, the question of gay marriage and abortion remains a highly contentious and ongoing issue within this society. For example, since its establishment in 1998, the Northern Ireland Assembly has voted on a number of separate occasions to prohibit either same-sex marriage or the extension of the 1967 Abortion Act in Britain to Northern Ireland (Hayes and Nagle 2016; Thomson, 2016).

\section{Believing and belonging: towards a conceptual framework}

Sociologists have long recognised that religion is a multidimensional phenomenon, encompassing aspects of belief, practice and identity. Only more recently have sociologists of religion begun to also recognise the multiple dimensions and complexity of non-religion (Lee, 2012), or try to make conceptual and empirical sense of the 'fuzziness' that lies between religion and non-religion (Storm, 2009; Voas, 2009; Voas and Day, 2010; Stolz et al., 2016). One of the attempts to capture some of the complexity in a parsimonious way has arisen following Grace Davie's (1994) description of religiosity in Britain as 'believing without belonging.' Davie raised the question about the extent to which individuals in Britain, and indeed many western European nations, continue to hold on to 'deep-seated religious aspirations', despite a notable decline in church attendance and other measures of religious practice. According to Davie, many Britons, continue to believe - albeit, in a fuzzier, less creedal sense - without attending church regularly, or even infrequently. As Davie $(1994,463)$ put it: 'More and more people within British society are, it appears, wanting to believe but without putting their belief in practice.' Davie thus argued that religious practices and beliefs could be distinguished analytically, and were at least partially independent of each other.

This contention marked the beginning of some controversy with Davie's thesis attracting criticism from sociologists who adhere to a more traditional theory of secularisation, in which it is generally presumed that belief and practice cannot be separated, at least not in the long-run. They argued that what Davie was pointing to was, at most, a transitional phase in the trajectory of secularisation (Voas and Crockett 2005; Voas 2009). If regular church attendance declines ahead of belief, so the argument goes, we can assume that belief's demise cannot be far behind. This now famous phrase has nevertheless resonated with a number of scholars, both as a theme 
and in its variations. It has also prompted a consideration of the other quadrants of the typology that can be logically extrapolated from this phrase: sociologists have long recognised that some people are neither believing nor belonging, and others are both believing and belonging. However, besides the two above derivatives, there is also an additional category - those who belong without believing. Such non-believing attenders have often been either ignored, or at least considered to be socially and politically insignificant.

Nevertheless, Nordic scholars and those studying religion in the region have found this quadrant of the typology - belonging without believing - the most useful as a means of characterising their societies. Those who are 'belonging without believing' or 'the culturally religious', are those who remain strongly attached to their churches and occasionally participate in its rituals without believing in God or other key tenets of the Christian faith (Zuckerman 2008; Kasselstrand 2015). This phrase has not only been applied as an apt description for scholars writing about established Protestant churches in Scandinavia, but it has also been adopted by some sociologists writing about predominantly Catholic countries, presenting it as a characteristic of a proportion of the population both of Italy (Garelli 2013) and the Republic of Ireland. As Inglis $(2007,216)$, in pointing to the emergence of what he termed 'individualist Catholics' in the Republic of Ireland, put it: 'The proportion (88\%) who go to Mass about once a month or more often is striking. As in Italy and Spain, it is higher than the proportion who believe in life after death. Is this evidence of a new type of Catholic who likes to go to Mass for the experience and sense of community - a case of belonging without believing?'

In summary, the link between religious practice and belief remains a highly contested and complex issue. This is particularly the case in Europe where the study of religious change has revolved around a debate about the nature and extent of secularisation. For example, some scholars point to a direct downward link between religious belief and belonging - or a movement from the most religiously committed (those who believe and belong) to the wholly secular (those who neither believe nor belong) - in terms of the changing religious landscape within these societies (Crockett and Voas 2005). Others, however, suggest an inverse effect between religious belief and belonging; namely the growth in a more 'fuzzy' or 'distanced' type of religious 
fidelity, or the rise in those who believe but do not belong as well as those who continue to belong but do not believe (Davie 2002; Storm 2009; Stolz et al. 2016). It is with this complexity in mind that this article focuses on the relationship between religion and moral attitudes in Northern Ireland. More specifically, applying the fourfold typology - the intersection between believing and belonging - it seeks to assess the degree to which individuals who belong but who do not believe, the most understudied group, hold distinct views in terms of their attitudes towards gay marriage and reproductive rights within this society.

\section{Data and methods}

The data used in the analysis come from the 2015 Northern Ireland Election Survey. ${ }^{2}$ Conducted immediately after the Northern Ireland Westminster Election in May 2015, the Northern Ireland Election Survey was a nationally representative survey of all adults aged 18 or older. Using a questionnaire design, it is based on face-to face interviews involving 1,810 adults, with a response rate of 68.3 per cent. Given our main focus of interest, the impact of religion on attitudes towards the legalisation of gay marriage and abortion rights, only the two main religious groupings - Catholics and Protestants - in Northern Ireland are included in the investigation. This accounts for 1,464 individuals or 80.9 per cent of the total sample. ${ }^{3}$ Attitudes towards same-sex marriage and abortion rights, our two dependent variables of interest, are operationalised in terms of two single-item measures, namely levels of support or opposition to the legalisation of gay marriage or abortion in Northern Ireland. More specifically, respondents were asked to agree or disagree with the statements 'Gay marriage should be made legal in Northern Ireland' and 'Abortion should be made legal in Northern Ireland' using a five-point Likert scale, from strongly agree to strongly disagree. The abortion question offers no qualifications, either in the statement, nor as options in the response, as to under what conditions the respondent feels an abortion should be a legal option (for example, when the mother's life is at risk - currently permitted - or in cases of rape and incest, or other defined special conditions).

Religion, our primary explanatory variable of interest, is operationalised in terms of the typology of believing and belonging. As in previous research, whereas 
belief is defined as a belief in God, belonging is operationalised as a regular church attender. And, while we acknowledge that there is some disagreement about how 'belonging' should be operationalised - either as a matter of identity or participation we adhere to the latter view that 'belonging' is best captured by an indicator of active participation, in practice, regular church attendance (Francis and Robbins 2004). Sociologists from a variety of theoretical perspectives have assumed that belief and practice must correspond, at least in the medium term. However, the Davie typology calls into question this assumption. Following Voas and Day's $(2010,5)$ suggestion as to the need for some further investigation of this issue, we also seek to examine the connection between belief and practice empirically.

Religious belief and religious practice are both complex, multidimensional phenomena, as scholars of lived religion and lived non-religion would observe (McGuire 2008; Ammerman 2014). Most measures of religion are blunt instruments and better suited to understanding Christian groups with clear commitment and narrowly conventional (especially Protestant) beliefs (Wuthnow 2014). Further, there are limitations inherent in reducing 'belief' to a single variable with degrees of belief in God, or practice to frequency of church attendance. Although there are limits to what one can say on the basis of these restricted measures, we are fortunate to have such data available for analysis, given the relative infrequency with which representative surveys, especially outside of the United States, ask questions about substantive religious beliefs.

In addition, we include a number of socio-demographic control variables, such as religious affiliation, gender, marital status, age, education, occupation, and employment status. Previous studies in the United States, Britain, Northern Ireland, and elsewhere in Europe, show that women, the unmarried, the young and the socioeconomically privileged, are notably more tolerant in their views towards gay marriage and reproductive rights compared with men, married people, older individuals and the lesser-privileged. The influence of religious identity is dependent on the particular moral attribute that is to be investigated (Jelen and Wilcox 2003, 2005; Olsen et al., 2006; Froese and Bader 2010; Barkan 2014; Clements 2014; Hayes and Dowds 2015; Lizotte 2015). For example, previous research in Northern Ireland and elsewhere suggests that while Catholics are more supportive of gay marriage than 
Protestants, they tend to be less supportive of abortion rights, particularly when comparisons to non-evangelical or mainline Protestants are considered (Hayes and McAllister,1995; Jelen and Wilcox 2003; Hoffman and Johnson 2005; Fahey et al. 2006; Clements 2014; Hayes and Nagle 2016). With the exception of age (coded in years), all control variables were included as a series of dummy variables (coded 0 and 1) in the analysis. The investigation proceeds in two stages. First, applying the typology developed by Davie, we examine the analytical link between religious belief and practice by outlining the numerical composition on all four groups among the adult population in Northern Ireland as well as by highlighting any differences in socio-economic background between them. Building on this investigation and using multivariate regression analysis, we then focus on the degree to which these differing intersections of belief and practice - particularly among those who belong but do not believe - are a key distinguishing factor in predicting attitudes towards gay marriage and reproductive rights within this society.

\section{Believing and belonging: operationalising the typology}

Table 1 begins the investigation by examining the nature and extent of religious belief and practice in Northern Ireland. A key focus of this investigation is to illustrate the degree to which religious belief and practice are intertwined within this society. As in previous research, the results suggest that Northern Ireland remains a deeply religious society and this is particularly the case when religious belief is considered. While nearly seven in every ten respondents, or 68 per cent of the adult population, claim to believe in God - either with or without doubts - less than one-third say that they do not. Moreover, among those who expressed a belief in God, the vast majority reported that they believed without any doubt. This pattern is repeated when non-believers are considered; among the latter it is intermittent belief rather than non-belief, which is the most reported category.

\section{[Insert Table 1 about here]}

A similar, albeit somewhat converse, result emerges when religious observance, or church attendance rates, are considered. While just over two-fifths of individuals, or 44 per cent, claimed to attend church on a regular or at least monthly basis, a majority - or 56 per cent - did not. It is important to note, however, among 
the latter, that it is less frequent church attendance rather than complete nonattendance which is the most dominant pattern. For example, whereas 46 per cent of all respondents stated that they attended church on a less than monthly basis, the equivalent proportion among those who never attended was just 10 per cent. Thus, at least as far as religious belief and observance in Northern Ireland is concerned, there is some indirect evidence to suggest that in addition to those who believe and belong the most religiously committed group - there is also a sizeable proportion of the adult population that believe but do not belong.

To investigate this issue directly, Figure 1 presents the relationship between religious belief and practice. For the purposes of this investigation and in line with Davie's typology, four groups are distinguished in the analysis: individuals who believe and belong; individuals who belong but do not believe; individuals who believe but do not belong; and individuals who neither believe nor belong. As the data in Figure 1 indicates, while the most religiously committed - those who believe and belong - are the largest group at 36 per cent, there is also a notable and almost equivalent number of individuals who believe but do not belong, or exactly a third in this instance. This is not to discount, however, the relatively large number of respondents who may be considered wholly secular - who neither believe nor belong - at just over a fifth, or 23 per cent in this instance, as well as the small minority of individuals who belong but do not believe ( 8 per cent), otherwise known as the culturally religious, or as Davie $(2000,3)$ put it: '[those] who believe in belonging' (see also Day 2011).

[Insert Figure 1 about here]

\section{Who are the culturally religious - those who belong but do not believe?}

While much research attention has been paid to the socio-demographic or background characteristics of those who believe and do not belong or to those who neither believe nor belong, this is not the case when the culturally religious, or those who belong but do not believe, are considered (Storm 2009). The few studies, albeit predominantly European, that do exist suggest that in comparison to both the most secular and 
religiously committed, those who do not believe but belong, are more likely to be male, younger, lesser educated and, when confronted by a Protestant majority, such as in Northern Ireland, they are predominantly drawn from the Catholic tradition (Storm 2009; Kasselstrand 2015; Bullivant 2016; Stolz et al., 2016). A somewhat more mixed pattern is echoed when those who believe but do not belong are considered, who are again disproportionally male and young but, in this instance, are drawn from among the more educated members of society (Demerath, 2000; Voas 2009; Storm 2009; Wilkins-Laflamme 2014).

To what extent do similar differences occur when the culturally religious those who belong but do not believe - in Northern Ireland are considered? Table 2 addresses this question. As in our earlier investigation in Figure 1, four religious groupings are again distinguished in the analysis with those who belong but do not believe - the culturally religious - as the baseline category of comparison. The results in Table 2, however, lend only partial support to earlier findings from previous research in the area. Although there were some notable differences in sociodemographic background between the culturally religious and the other religious groupings, only in relation to those who were wholly secular - those who neither believe nor belong - are these differences almost uniform and also markedly distinctive.

Focusing initially on respondents who attend church on a regular basis, only in relation to religious affiliation, age and employment status, are there any notable differences between the two groups in relation to this issue. In comparison to the most religiously committed, not only are the culturally religious significantly more likely to be Catholic but they are also notably more likely to be drawn from the younger and employed sections of the adult population. For example, whereas two-thirds of the culturally religious are members of the Catholic faith, the equivalent proportion among the most religious - those who both believe and belong - is markedly lower at just 48 per cent. A similar finding is echoed when age is considered; younger adults are notably more likely to belong but not believe as compared to their more religiously committed counterparts.

[Insert Table 2 about here] 
A much more pronounced pattern of difference emerges when comparisons to the non-attenders at religious services are considered and this is particularly the case when those who neither believe nor belong are examined. Here, on all but one attribute - non-manual occupation - there are marked differences between the two groups in terms of their demographic makeup. In comparison to those who neither believe nor belong, whereas those who belong but do not believe were again significantly more likely to be Catholic and, in this instance, drawn from both the well-educated and employed section of the adult population, they were also more likely to be female, married and aged between 18-45 years. For example, while 66 per cent of the culturally religious were members of the Catholic faith and 61 per cent were female, the equivalent proportions among the wholly secular were just 33 per cent and 47 per cent, respectively. This is not the case, however, when the younger members of society, or those aged 18-45 years, were considered; just half of those who did not believe but attended church on a regular basis fell into this category as compared to 66 per cent among the wholly secular. With two notable exceptions marital and employment status - these findings are repeated when the sociodemographic profile of those who belong but do not believe versus those who believe but do not belong is compared.

In summary, the results are clear: those who belong but do not believe, or the culturally religious, are more likely to be female, married, among the better educated, and drawn from the Catholic tradition. Moreover, this relationship holds irrespective of whether a comparison with the most religiously committed or those who do not believe or attend are considered. There is also evidence to suggest that while the culturally religious are somewhat similar in their socio-demographic profile to the most religiously committed as well as to those who believe but do not belong, this is not the case when the wholly secular is considered where marked differences occurred in relation to this issue.

\section{Belief, belonging, and attitudes towards gay marriage and abortion}

As noted earlier, previous research on gay marriage and abortion rights finds that religious factors, such as affiliation, regular church attendance and beliefs in and about God, are among the most frequent net predictors of opposition to gay marriage 
and abortion rights. To what extent is this also the case when the intersection between religious beliefs and practices, or the Davie typology, is considered? In other words, are there notable differences between those who belong and do not believe, and the other religiously-defined groups? Table 3 addressed this question. As in our earlier analysis four groups are distinguished in the investigation with individuals who belong but do not believe - the culturally religious - as our baseline category of comparison. The results are clear. Irrespective of whether support for gay marriage or abortion are considered, there are notable differences among attenders. Individuals who belong but do not believe are much more supportive in their views than the most religiously committed. This is not the case in comparison with non-attenders, where respondents express quite similar views, regardless of whether or not they are believers.

Focusing initially on the attitudes towards gay marriage among the attenders, here it is non-believers, or the culturally religious, that stand out as the most liberal in their views. For example, whereas two-thirds of those who belong but do not believe agree with gay marriage, the equivalent proportion among the most religiously committed - those who both belong and believe - was notably lower at just 38 per cent. A similar, albeit converse, pattern emerges when lack of support is considered and this is particularly the case among those who strongly disagree. For example, whereas just nine per cent of non-believers who attend church on a monthly basis were strongly opposed to the legalisation of gay marriage and a further six per cent were opposed, the equivalent cumulative proportion among those who both believe and attend was nearly treble this amount at 44 per cent, or 30 per cent and 14 per cent, respectively. Thus at least as far as attenders are concerned, it is those who belong but do not believe who are the most liberal in their views.

\section{[Insert Table 3 about here]}

This is not the case, however, when attitudes among the culturally religious and those who do not attend religious services are compared, where no major differences emerged in terms of their views. For example, whereas 60 per cent of those who believe but do not belong agree with gay marriage or just six percentage points less than our reference group (those who belong but do not believe), the 
equivalent proportion among the wholly secular was just two percentage points lower at 58 per cent. A similar pattern emerges when those who oppose gay marriage are considered. While an almost identical proportion of the wholly secular and the culturally religious - 17 per cent as compared to 15 per cent - disagreed with gay marriage, the equivalent percentage among those who believe but do not belong is somewhat higher at 27 per cent. This is not to discount, however, the much higher proportion of individuals overall, or 52 per cent in this instance, who agree with the legalisation of gay marriage as compared to just 30 per cent who are opposed to such an initiative.

These patterns are replicated when attitudes towards abortion are considered, although it should be noted that levels of support are somewhat lower in this instance. Focusing initially on the attenders, again it is non-believers, or the culturally religious, that stand out as the most liberal in their views. For example, whereas just over half of those who belong but do not believe agree with the legalisation of abortion, the equivalent proportion among the most religiously committed - those who both belong and believe - was nearly half this amount at just 29 per cent. By contrast, while just 19 per cent of non-believers who attend church on a monthly basis were opposed to abortion rights, the equivalent proportion among the most religiously committed, or believers who attend, is twenty-eight percentage points higher at 47 per cent. Thus, at least as far as attitudes towards abortion among the attenders are concerned, it is again those who belong but do not believe who stand out as the most supportive in their views.

Again, this is not the case, however, when attitudes among the culturally religious are compared with those who do not attend church services, where no major differences emerged in terms of their views. For example, whereas 51 per cent of those who believe but do not belong support abortion, or just two percentage points less than our reference group (those who belong but do not believe), the equivalent proportion among the wholly secular is just five percentage points higher at 56 per cent. A similar pattern emerges when those who oppose abortion are considered. While an almost identical proportion of the wholly secular and culturally religious 20 per cent as compared to 19 per cent - disagreed with abortion, the equivalent percentage among those who believe but do not belong is just six percentage points 
higher at 26 per cent. This is not to discount, however, the higher proportion of individuals overall, or 44 per cent in this instance, who agree with the legalisation of abortion as compared to just 31 per cent who are opposed to such an initiative.

To what extent do these differences among the attenders remain when a range of background control variables, such as religious affiliation, gender, marital status, age and socio-economic background, are included in the analysis? Table 4 addresses this question. ${ }^{4}$ The results are clear. Irrespective of whether attitudes towards gay marriage or abortion are considered, while there are no notable differences between the culturally religious and non-attenders in relation to this issue, this is not the case when the most religiously committed are considered who are notably different, or less supportive, in their views. Even when a range of background variables, such as religious affiliation, gender, marital status, age and socio-economic status, are included in the analysis, the most religiously committed, or individuals who believe and belong, are significantly less likely to support the legalisation of gay marriage and abortion than the culturally religious, or those who belong but do not believe (the omitted category for comparison).

\section{[Insert Table 4 about here]}

This is not to suggest, however, that religiosity, or the intersection between religious belief and practice, is the sole predictor of attitudes in this instance. Other significant net determinants include the consistent effects of religious affiliation, gender, age and educational attainment. While females and the educated were notably more supportive of both gay marriage and abortion rights than either males or those with no educational qualifications, older individuals were significantly more negative than their younger counterparts in term of their views. A somewhat more complex pattern emerges when the effect of religious affiliation is considered. As in previous research, while Catholics were notably more likely to support gay marriage than Protestants, they were significantly less likely to do so when the question of abortion rights is considered.

\section{Conclusion}


Over the last few decades there has been a dramatic change in public attitudes towards gay rights in the United States, Great Britain and elsewhere in Europe. Although same-sex relations remain a perennial topic of debate within these societies, the overall trend has been a growing acceptance of gay rights and increasing legislative protection for these rights. This is not to negate, however, substantial cross-national variation in relation to this issue, particularly when the issue of same-sex unions, or gay marriage, is considered. Although same-sex relations in general seem to be more widely accepted than a few decades ago, the extent to which same-sex unions are similarly endorsed differs considerably both within and between nations. In fact, some commentators have suggested that disputes over gay rights, such as the legal recognition of same-sex unions, have now replaced abortion rights as one of the most contentious and divisive issues in contemporary western democracies.

It has long been established that religious affiliation, belief and behaviour are associated with an individual's attitudes towards same-sex relations and gay rights. This is also the case when attitudes towards same-sex marriage are considered. There is now a growing body of research to suggest that people who are the most opposed to gay marriages tend to be more religiously devout on a variety of measures such as attachment, belief and practice. In fact, previous research demonstrates that such religious factors are among the strongest predictors of variation in public opinion towards gay marriage and abortion rights. Yet, what we know about the effect of religion on both gay marriage and abortion rights remains somewhat limited. This is particularly so when the intersection of religious belief and belonging is investigated. Although much attention has been paid to the net effects of these religious measures on attitudes towards gay marriage and abortion rights, to date the intersection of these two factors in determining public views has not been investigated. This is particularly the case for those who belong but do not believe, who have been dismissed in the literature as illogical or at best a transitory stage, as well as socially and politically irrelevant.

The results of this investigation, however, call into question both these assumptions. Our arguments in support of this proposition are threefold. First, at eight per cent of the population, those who belong but do not believe, or the culturally religious, form a notable minority group within Northern Irish society. Second, there 
is also some evidence to suggest that at least as far as their socio-demographic profile is concerned, the culturally religious may be considered a distinct group. As the results of this investigation also demonstrate, not only are those who belong but do not believe disproportionately drawn from the Catholic tradition, but they are also significantly more likely to be female, married, and among the better-educated members of society. Moreover, this relationship holds regardless of whether comparisons with either the most religiously committed or those who neither believe nor belong are considered. Finally, at least in comparison with the most religiously committed, those who belong but do not believe are also distinctive in terms of their views on new morality issues, such as gay marriage and abortion rights. Irrespective of whether attitudes towards the legalisation of gay marriage or abortion are considered, the culturally religious, or those who belong but do not believe, stand out as significantly more supportive of both these issues than the most religiously committed. Moreover, this relationship remains regardless of whether or not sociodemographic factors are taken into account.

These findings have a number of implications for future research in this area. First, while religion plays a crucial role in shaping public perceptions of moral issues, such as gay marriage and abortion rights, the impact of religion is both complex and variable and this is particularly the case when the intersection between belief and practice is considered. As the results of this study demonstrates clearly, while no notable differences emerged in comparison to the non-attenders, those who belong but do not believe, or the culturally religious, are notably more likely to adopt a liberal stance in relation to both these issues than the most religiously committed, or those who both belong and believe. It is to a further investigation of this issue, or the intersection between belief and practice, that future research should be directed. Second, particular attention should be paid to the religious and spiritual background as well as the motivations of those who belong but do not believe. For example, previous research based on the culturally religious in continental Europe suggests that one key factor in accounting for their attendance is their attachment to their national churches as a marker of cultural belonging and a historical heritage (Kasselstrand 2015). Further, future studies should also focus on the long-term impact of this divergence in moral views among regular attenders. For example, previous research suggests that 
persons who attend diverse congregations, such as those with a multiracial composition, are notably more likely to support gay marriage and adoption than those who attend more racially homogeneous ones (Perry 2013). To what extent will similar results, or an increasing congruency in moral outlooks, also emerge when the longterm impact of differences in religious belief among the attenders are considered? Finally, the present research also points to the need for complementary on-the-ground qualitative studies to provide a more fine-grained and nuanced investigation of this understudied minority, those who belong but do not believe, both in terms of their reasons for religious participation and their relations with others, both believers and non-believers as well as those who attend church services and those who do not. As a distinct, theoretically and empirically important minority within Northern Ireland, and elsewhere, there is much to be learned about both their (un)belief and their participation as well as their views on a range of moral and socio-political issues. 


\section{Endnotes}

1 Unlike the rest of the UK, where same-sex marriages were granted legal status in 2014, this is not the case in Northern Ireland where, since 2004, legal status is restricted to civil-partnerships among gay couples. Similarly, unlike the rest of the UK which allows for abortion up to 24 weeks with the permission of two doctors under the aegis of the 1967 Abortion Act, abortion is only permitted in Northern Ireland if a woman's life is at risk or if there is a permanent or serious risk to her mental and physical health (Thomson, 2016).

2 The 2015 Northern Ireland General Election Survey was collected by Jonathan Tonge, Jocelyn Evans, Bernadette C. Hayes, Paul Mitchell and Peter Shirlow and funded by the Economic and Social Research Council (Grant Number: ES/L007320/1). The data is publicly available from the UK Data Service.

3 Alternative analyses, which also included either religious independents (those who currently claim to have no religious affiliation) or the total sample, gave rise to identical substantive conclusions in terms of the effect of our primary variable of interest, namely the impact of religious belief and attachment on attitudes towards gay marriage and abortion rights.

An alternative analysis which included belonging and believing as two separate variables in the regression equation indicated that both were significant net determinants of attitudes towards gay marriage and abortion. Moreover, other significant net determinants in the model, such as the consistent effects of religious affiliation, gender, age and educational attainment were identical in this instance, although it should be noted that the R-squared, or proportion of variance explained, was somewhat lower in this analysis than in the combined, or four-category, investigation. 


\section{References}

Ammerman, N.T. 2014. 'Finding religion in everyday life.' Sociology of Religion. 75(2): 189-207.

Badgett, M.V. Lee. 2009. When Gay People Get Married: What Happens When Societies Legalize Same-Sex Marriage. New York: New York University Press.

Barkan, Steven. 2014. 'Gender and Abortion Attitudes: Religiosity As A Suppressor Variable.' Public Opinion Quarterly. 78(4): 940-950.

Brewer, Paul R. 2014. 'Public Opinion About Gay Rights and Gay Marriage.' International Journal of Public Opinion. 26(3): 279-282.

Brittain, C.C. and A. McKinnon. 2018. The Anglican Communion at a Crossroads: The Crises of a Global Church. University Park: Penn State University Press.

Bullivant, S., 2016. 'Catholic disaffiliation in Britain: a quantitative overview'. Journal of Contemporary Religion. 31(2): 181-197.

Clements, Ben. 2014. 'Religion and the Sources of Public Opposition to Abortion in Britain: The Role of "Belonging", "Behaving" and "Believing." Sociology. 48(2): 369-386.

Clements, Ben. 2015. Religion and Public Opinion in Britain: Continuity and Change. Palgrave Macmillan.

Clements, Ben and Clive D. Field. 2014. 'Public Opinion Towards Homosexuality and Gay Rights in Britain.' Public Opinion Quarterly. 78(2): 523-547.

Davie, Grace. 1994. Religion in Britain since 1945: Believing Without Belonging. Wiley-Blackwell.

Davie, Grace. 2002. 'Praying Alone? Church-Going in Britain and Social Capital: A Reply to Steve Bruce.' Journal of Contemporary Religion. 17(3): 329-334.

Davie, Grace. 2000. Religion in Modern Europe: A Memory Mutates. Oxford: Oxford University Press.

Davie, Grace. 2015. Religion in Britain: A Persistent Paradox. West Sussex, UK: John Wiley \& Sons.

Day, A., 2011. Believing in belonging: Belief and social identity in the modern world. Oxford: Oxford University Press.

Demerath III, N. J. 2000. 'The Rise of "Cultural Religion" in European Christianity: Learning from Poland, Northern Ireland, and Sweden.' Social Compass. 47(1): 127-139.

Fahey, Tony, Hayes, Bernadette C. and Richard Sinnott. 2006. Conflict and Census: A Study of Values and Attitudes in the Republic of Ireland and Northern Ireland. London: Brill.

Fitzgerald, Rory, Winstone, Lizzy and Yvette Prestage. 2014. 'Searching for Evidence of Acculturation: Attitudes Towards Homosexuality Among Migrants Moving From Eastern to Western Europe.' International Journal of Public Opinion. 26(3): 323-341. 
Francis, Leslie J. and Mandy Robbins. 2004 'Belonging without Believing: A Study in Social Significance of Anglican Identity and Implicit Religion Among 13-15 year-old Males.' Implicit Religion. 7(1): 37-54.

Froese, Paul and Christopher Bader. 2010. America's Four Gods: What We Say About God - \& What That Says About Us. Oxford: Oxford University Press.

Garelli, Franco. 2013. 'Catholiques, Politique et Culture. Le Cas Italien.' Social Compass. 60(3): 332-347.

Hayes, Bernadette C. and Lizanne Dowds (2015) 'Religion and Attitudes Towards Gay Rights in Northern Ireland: The God Gap Revisited.' In Stanley D. Brunn (ed.), The Changing World Religion Map: Sacred Places, Identities, Practices and Politics. New York: Springer, pp. 3321-3340.

Hayes, Bernadette C. and Ian McAllister (1995) 'Religious Independents in Northern Ireland: Origins, Attitudes and Significance.' Review of Religious Research. 37(1): 65-83.

Hayes, Bernadette C. and Ian McAllister (2013) Conflict to Peace: Politics and Society in Northern Ireland Over Half a Century. Manchester: Manchester University Press.

Hayes, Bernadette C. and John Nagle (2016) 'Ethnonationalism and Attitudes Towards Gay and Lesbian Rights in Northern Ireland.' Nations and Nationalism. 22(1): 20-41.

Hoffmann, John P. and Sherrie Mills Johnson. 2005. 'Attitudes Toward Abortion Among Religious Traditions in the United States: Change or Continuity?' Sociology of Religion. 66(2): 161-182.

Inglis, Tom. 2007. 'Catholic Identity in Contemporary Ireland: Belief and Belonging to Tradition 1.' Journal of Contemporary Religion. 22(2): 205-220.

Jelen, Ted G. and Clyde Wilcox. 2003. 'Causes and Consequences of Public Attitudes Toward Abortion: A Review and Research Agenda.' Political Research Quarterly. 56(4): 489-500.

Jelen, Ted G. and Clyde Wilcox. 2005. 'Continuity and Change in Attitudes Toward Abortion: Poland and the United States.' Politics \& Gender. 1(2): 297-317.

Kasselstrand, Isabella. 2015. 'Nonbelievers in the Church: A Study of Cultural Religion in Sweden.' Sociology of Religion. 76(3): 275-294.

Lee, Lois. 2012. 'Research Note: Talking About Revolution: Terminology for the New Field of Non-Religion Studies.' Journal of Contemporary Religion. 27(1): 129-139.

Lizotte, Mary-Kate. 2015. 'The Abortion Attitudes Paradox: Model Specification and Gender Differences.' Journal of Women, Politics \& Policy. 36(1): 22-42.

McGuire, M.B. 2008. Lived Religion: Faith and Practice in Everyday Life. Oxford: Oxford University Press.

McKinnon, Andrew M. 2003. 'The Religious, the Paranormal, and Church Attendance: A Response to Orenstein.' Journal for the Scientific Study of Religion. 42(2): 299-303. 
McKinnon, A.M., M. Trzebiatowska, and C. C. Brittain. 2011. 'Bourdieu, Capital, and Conflict in a Religious Field: The Case of the 'Homosexuality' Conflict in the Anglican Communion.' Journal of Contemporary Religion. 26(3): 355-370.

Olson, Laura R., Cadge, Wendy and James T. Harrison. 2006. 'Religion and Public Opinion about Same-Sex Marriage.' Social Science Quarterly. 87(2): 340-359.

Paxton, P., Reith, N.E. and J. L. Glanville. 2014. 'Volunteering and the dimensions of religiosity: A cross-national analysis'. Review of Religious Research. 56(4): 597-625.

Perry, Samuel L. 2013. 'Multiracial Church Attendance and Support for Same-Sex Romantic and Family Relationships.' Sociological Inquiry. 83(2): 259-285.

Pew Research Centre. 2016. 'Gay Marriage Around the World.' http://www.pewforum.org/2015/06/26/gay-marriage-around-the-world-2013/, accessed 2 July 2016.

Schieman, S., Bierman, A., Upenieks, L. and C. G. Ellison. 2017. 'Love Thy Self? How Belief in a Supportive God Shapes Self-Esteem'. Review of Religious Research. 59(3): 293-318.

Stolz, Jorg, Konemann, Judith, Purdie, Mallory Schneuwly, Englberger, Thomas and Mitchael Kruggeler. 2016. (Un)Believing in Modern Society: Religion, Spirituality, and Religious-Secular Competition. London: Routledge.

Storm, Ingrid. 2009. 'Halfway to Heaven: Four Types of Fuzzy Fidelity in Europe.' Journal for the Scientific Study of Religion. 48(4): 702-718.

Thomson, Jennifer. 2016. 'Abortion and Same-Sex Marriage: How Are Non-Sectarian Controversial Issues Discussed in Northern Ireland Politics?' Irish Political Studies. 31(4): 483-501.

Voas, David. 2009. 'The Rise and Fall of Fuzzy Fidelity in Europe.' European Sociological Review. 25(2): 155-168.

Voas, David and Alasdair Crockett. 2005. 'Religion in Britain: Neither Believing Nor Belonging.' Sociology. 39(1): 11-28.

Voas, David. 2009. 'The Rise and Fall of Fuzzy Fidelity in Europe.' European Sociological Review. 25(2): 155-168.

Voas, David and Abby Day. 2010. Recognising Secular Christians: Towards an Excluded Middle in the Study of Religion. Association of Religion Data Archives. [see: http://www.thearda.com/]

Whitehead, Andrew L. 2010. 'Sacred Rites and Civil Rights: Religion's Effect on Attitudes Towards Same-Sex Unions and the Perceived Cause of Homosexuality.' Social Science Quarterly. 91(1): 63-79.

Wilcox, Clyde. 2007. 'Preface.' In Craig A Rimmerman and Clyde Wilcox (Eds.), The Politics of Same-Sex Marriage. London: University of Chicago Press, pp ix$\mathrm{xV}$.

Wilkins-Laflamme, Sarah. 2014. 'Towards Religious Polarization? Time Effects on Religious Commitment in U.S., UK, and Canadian Regions.' Sociology of Religion. 75(2): 284-308. 
Wuthnow, R., 2015. Inventing American Religion: Polls, Surveys, and the Tenuous Quest for a Nation's Faith. Oxford: Oxford University Press.

Zuckerman, Phil. 2008. Society without God: What the Least Religious Nations Can Tell Us About Contentment. New York: New York University Press. 
Table 1: Religious belief and practice in Northern Ireland

\begin{tabular}{lc}
\hline & (Percentages) \\
\hline Belief in God: & 68.4 \\
Yes & $(42.7)$ \\
Believe with no doubts & $(25.7)$ \\
Believe with doubts & 31.6 \\
No & $(19.0)$ \\
Only some of the time & $(12.6)$ \\
Do not believe & 100.0 \\
Total & {$[1,448]$} \\
[N] & \\
& \\
Church Attendance: & 44.1 \\
Regular & $(16.3)$ \\
Weekly & $(27.8)$ \\
Monthly & 55.9 \\
Irregular & $(45.7)$ \\
Less than monthly & $(10.2)$ \\
Never & 100.0 \\
Total & {$[1,448]$} \\
[N] & \\
\hline
\end{tabular}

Source: Northern Ireland General Election Survey, 2015

Figure 1: A Typology of religious belief and practice

\begin{tabular}{|c|c|c|}
\hline \multirow{2}{*}{$\begin{array}{c}\text { Religious } \\
\text { Practice }\end{array}$} & Yes & Religious Belief \\
\hline Regular & $\begin{array}{c}\text { No } \\
\text { Believing and Belonging } \\
(35.7 \%)\end{array}$ & $\begin{array}{c}\text { Belonging without } \\
\text { Believing } \\
(8.3 \%)\end{array}$ \\
\hline Irregular & $\begin{array}{c}\text { Believing without } \\
\text { Belonging } \\
(32.9 \%)\end{array}$ & $\begin{array}{c}\text { Neither Believing nor } \\
\text { Belonging } \\
(23.1 \%)\end{array}$ \\
\hline
\end{tabular}

Source: Northern Ireland General Election Survey, 2015. 
Table 2: Differences in background characteristics among those who belong and/or believe

\begin{tabular}{lcccc}
\hline & \multicolumn{3}{c}{ Attenders } & \multicolumn{2}{c}{ (Percentages) } \\
& $\begin{array}{c}\text { Belong } \\
\text { only }\end{array}$ & $\begin{array}{c}\text { Believe } \\
\text { and } \\
\text { Belong }\end{array}$ & $\begin{array}{c}\text { Believe } \\
\text { Only }\end{array}$ & $\begin{array}{c}\text { Neither Believe } \\
\text { nor Belong }\end{array}$ \\
\hline Catholic & 66.4 & $48.2^{*}$ & $38.6^{*}$ & $33.4^{*}$ \\
Female & 61.3 & 56.6 & $51.3^{*}$ & $47.0^{*}$ \\
Married & 69.0 & 65.9 & 61.3 & $56.2^{*}$ \\
Age (18-45 & 50.0 & $31.2^{*}$ & 52.3 & $65.7^{*}$ \\
years) & & & & $15.9^{*}$ \\
Tertiary- & 23.3 & 23.4 & $14.7^{*}$ & 24.7 \\
$\begin{array}{l}\text { Educated } \\
\text { Non-manual }\end{array}$ & 32.8 & 37.9 & 31.6 & $70.0^{*}$ \\
Labour active & 55.9 & $44.4^{*}$ & 57.1 & \\
\hline
\end{tabular}

Notes: * significantly different from Non-believers who attend church regularly at the 0.05 level (two-tailed).

Source: Northern Ireland General Election Survey, 2015.

Table 3: Differences in attitudes towards gay marriage and abortion among those who belong and/or believe

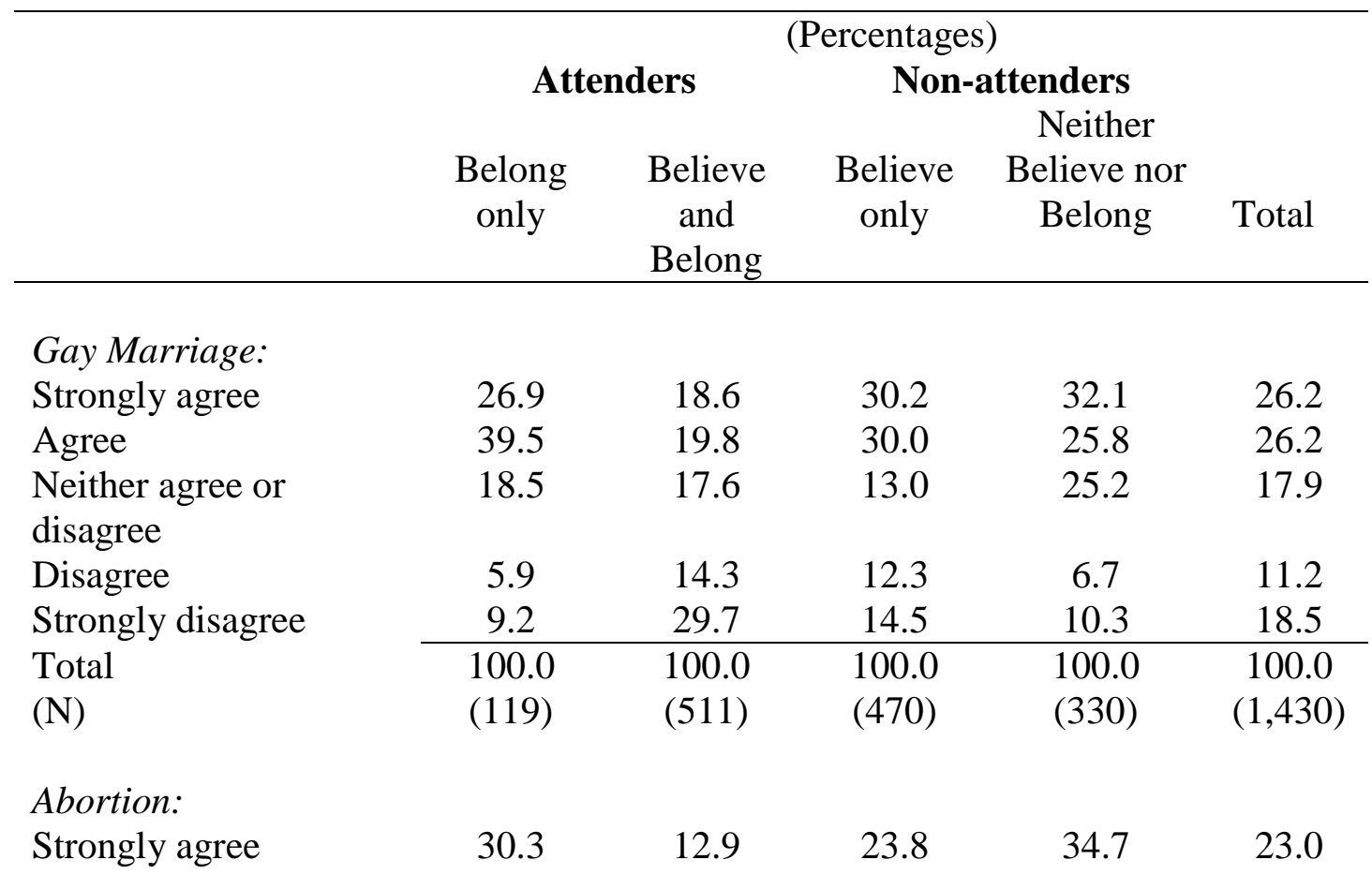




\begin{tabular}{lccccc} 
Agree & 22.7 & 15.7 & 27.6 & 20.8 & 21.4 \\
$\begin{array}{l}\text { Neither agree or } \\
\text { disagree }\end{array}$ & 28.6 & 24.9 & 22.5 & 24.8 & 24.4 \\
$\begin{array}{l}\text { Disagree } \\
\text { Strongly disagree }\end{array}$ & 12.6 & 16.3 & 12.3 & 8.8 & 12.9 \\
Total & 5.9 & 30.2 & 13.8 & 10.9 & 18.3 \\
\cline { 2 - 6 }$(\mathrm{N})$ & 100.0 & 100.0 & 100.0 & 100.0 & 100.0 \\
& $(119)$ & $(510)$ & $(510)$ & $(331)$ & $(1,431)$ \\
\hline
\end{tabular}

Questions: Gay marriage should be made legal in Northern Ireland; Abortion should be made legal in Northern Ireland.

Source: Northern Ireland General Election Survey, 2015. 
Table 4: The net effect of belonging without believing on attitudes towards gay marriage and abortion

\begin{tabular}{|c|c|c|c|c|}
\hline & \multicolumn{4}{|c|}{ Regression Coefficients (OLS) } \\
\hline & \multicolumn{2}{|c|}{ Gay Marriage } & \multicolumn{2}{|c|}{ Abortion } \\
\hline & $\mathrm{B}$ & beta & $\mathrm{b}$ & beta \\
\hline \multicolumn{5}{|l|}{ Control variables } \\
\hline Catholic & $0.09 * *$ & $(0.20)$ & $-0.03 *$ & $(-0.06)$ \\
\hline Female & $0.05 * *$ & $(0.11)$ & $0.03 *$ & $(0.06)$ \\
\hline Married & 0.01 & $(0.02)$ & 0.02 & $(0.03)$ \\
\hline Age (years) & $-0.01 * *$ & $(-0.29)$ & $-0.01 * *$ & $(-0.14)$ \\
\hline \multicolumn{5}{|l|}{ Education: } \\
\hline Tertiary & $0.05^{*}$ & $(0.08)$ & 0.01 & $(0.02)$ \\
\hline Secondary & $0.08 * *$ & $(0.18)$ & $0.04 *$ & $(0.09)$ \\
\hline No qualification ${ }^{\mathrm{a}}$ & --- & -- & --- & -- \\
\hline Non-manual & 0.01 & $(0.03)$ & $0.04 * *$ & $(0.08)$ \\
\hline Labour active & 0.02 & $(0.03)$ & 0.02 & $(0.05)$ \\
\hline \multicolumn{5}{|l|}{ Religiosity effect: } \\
\hline Belonging but not Believing ${ }^{\mathrm{a}}$ & --- & --- & --- & --- \\
\hline Believing and Belonging & $-0.09 * *$ & $(-0.19)$ & $-0.12 * *$ & $(-0.26)$ \\
\hline Believing but not Belonging & -0.03 & $(-0.05)$ & -0.03 & $(-0.07)$ \\
\hline Neither Believing nor & -0.02 & $(-0.04)$ & -0.01 & $(-0.03)$ \\
\hline \multicolumn{5}{|l|}{ Belonging } \\
\hline \multirow[t]{2}{*}{ Constant } & \multicolumn{4}{|c|}{$0.364 * *$} \\
\hline & $0.399 * *$ & & & \\
\hline $\begin{array}{l}\text { R-squared } \\
\text { (N) }\end{array}$ & $\begin{array}{r}.292 \\
(1,387)\end{array}$ & & $\begin{array}{r}.141 \\
(1,358)\end{array}$ & \\
\hline
\end{tabular}

Note: Attitudes towards the legalisation of gay marriage and abortion are coded from 0 (strongly disagree) to 1 (strongly agree); Standardised regression coefficients are in parentheses; ${ }^{\text {a }}$, omitted category of comparison; ${ }^{*}$, significant at the 0.05 level; **, significant at the 0.01 level.

Source: Northern Ireland General Election Survey, 2015. 